\title{
Disruption Communication Identity of Indonesia's Cyber Society on Instagram by Mimi Peri
}

\author{
Briant Nor Pradhuka ${ }^{1}$, Prahastiwi Utari ${ }^{2}$, and Sudarmo ${ }^{3}$ \\ \{briantnorpradhuka@student.uns.ac.id ${ }^{1}$ \} \\ 1,2,3 Universitas Sebelas Maret, Surakarta, Indonesia
}

\begin{abstract}
The 4.0 industrial revolution had enormous impacts. Such as, changes technology, economy, and even one's identity. This article will describe one of the impacts the industrial revolution 4.0 that occurred in Indonesia's cyber community. In this study will present the process disruption communication identity of Mimi Peri, its form, and its impact. Mimi Peri is a figure of Ahmad Jaelani's cyber communication identity innovation. With the communication-mediated computer (Instagram), Ahmad Jaelani communicates (self-presentation) his identity to other Instagram cyber communities. His initial step in identifying his identity, presents controversy for other Instagram cyber communities. Many people respond well and also respond badly. In this condition, Ahmad Jaelani still communicates his identity. The identity communication of Mimi Peri has a big influence on the displacement of the identity of the Instagram cyber Indonesia community, this action is referred to as a mass identity disorder. Ahmad Jaelani distorted three elements of his identity of communication, namely gender identity, language identity, and cultural protection identity. With this disruption Ahmad Jaelani became increasingly known, increasingly, and had many fans. Often, cyber society when seeing Ahmad Jaelani's actions want to emulate it, and make Ahmad Jaelani as a role model for communication identity disruption.
\end{abstract}

Keywords: disruption, communication identity, communication-mediated computer (CMC), Mimi Peri, Instagram

\section{INTRODUCATION}

This study focuses on the disruption of communication identity carried out by Ahmad Jaelani in his Instagram. Ahmad Jaelani innovated to do 'self-disruption' in the real world which was then disseminated and communicated to the cyber community through Instagram. This initial step of Ahmad Jaelani is one form of dynamics of communication-mediated computer (CMC) [1]. Which, cyber society as individuals and professionals, communicate, collaborate, consume, and create everything in social media [2]. The disruption of identity communication is also included in global studies, which are carried out by some of the world's cyber communities to display their cyber identity innovations. Like Jeffree Star, American Internet celebrity, showing his identity as a beauty vlogger. Sinon Loresca, Filipino Internet celebrity, shows his identity as a king of catwalk. 
The disruption of Ahmad Jaelani's communication identity was carried out on Instagram. Because Instagram is a popular social media [3]. The data from WeAreSocial and Hootsuite survey states, Instagram usage in 2018 found the seventh position in the world and the fourth largest in Indonesia [4]. The data explains that the dynamism of the cyber community has deepened on Instagram. They can take any action, such as: promotion [5], campaign [6], sharing sexual photos [7], narcissism [8], emotional delivery [9] and more. Ahmad Jaelani as an 'innovator of identity' using Instagram as an identity communication medium. This innovation will be known by cyber society as a disruption of communication identity.

Disruption is known as an innovation that turns the old system into a new system [10]. Disruption arises from advances in information technology [11]. The more information technology continues to advance, the greater the disruption spreads in various fields [12]. In the process, disruption does not occur immediately, but requires time and stages, such as the formation of ideas, concepts, innovations and so on [13]. The main purpose of the disruption of innovation is to make products or services have better performance [14]. The concept of disruption of innovation was first introduced by Christensen in the 1990s [15]. Which, Disruptiveness in innovation and technology is complex and not fully understood [15]. At the initial stage, disruption is often not realized and felt by the community [16]. Not infrequently innovation in disruption is known as 'a negative term' [17]. Which one of the effects of disruption of innovation changes the prevailing order and norms [13]. Like, the introduction of a series of new values [18] which are inversely proportional to the presumption of the general public.

While the disruption communication identity is an innovation in the process of conveying identity through the communication process. The theory of identity communication is formed, maintained, and modified through a communicative process [19]. There are two dimensions in this theory, namely subjective dimensions and uscribed dimension [19]. Subjective Dimension, identity is a feeling of personal self, while Ascribed Dimension is the opinion of others towards themselves [19]. Ahmad Jaelani communicates his virtual identity innovation as Mimi Peri. Mimi Peri is cyber communication identity as 'angel' created by Ahmad Jaelani [20]. Having a communication identity on Instagram as Mimi Peri, Ahmad Jaelani created a commotion. This commotion originated from an innovation of identity that was communicated to the public Instagram. The forms are like photo content, video, and direct interaction with other people (live Instagram). Ahmad Jaelani's action in sharing his identity through Instagram can be said to be a disruption of communication identity, where Ahmad Jaelani's 'angle' identity has shifted the concept of cyber Instagram community identity Indonesia.

\section{METHOD}

This study uses the content analysis method [21] to explain phenomenon of the disruption communication identity of Mimi Peri. In the form of disruption of Mimi Peri's communication identity, the process, the effect will be described. Sources of data in this study are: documents, news about him, video, his Instagram: Events that include the process of communicating Mimi Peri's communication identity, such as uploads and live Instagram (subjective dimensions); Mimi Peri's direct interaction with the cyber Instagram community, feedback and comments from cyber Instagram community (ascribed dimension). 


\section{FINDINGS AND DISCUSSION}

\subsection{The Process of disrupting the communication identity of Mimi Peri}

Mimi Peri is Ahmad Jaelani's cyber Instagram communication identity. Ahamad Jaelani is a Kendari man, Southeast Sulawesi who was born on June 13, 1988. Since the age of 3 years, he lived with his mother and siblings after his father was die. Since childhood, Ahmad Jaelani has a feminine nature, like he likes to play dolls. Responding to his son's condition, Ahmad Jaelani's mother has never protested the nature of his youngest child.

The process of disrupting the communication identity occurred when Ahmad Jaelani made unique clothes from materials around him. On that occasion, Ahmad Jaelani wore his design clothes to take pictures (the initial idea of Mimi Peri's identity appeared), such as newspapers, used tires, rating, and leaves. With his work, Ahmad Jaelani was nicknamed 'crazy' by Indonesian society and they rejected his creativity and innovation.

At the beginning of the innovation, Ahmad Jaelani's identity also received rejection from his family. Like, His Broters threatened to kill him if Ahmad Jaelani continued to behave like that. However, these opinions were never responded to by Ahmad Jaelani, he persisted with the innovation. Ahmadi Jaelani shared his innovation identity through Instagram in the form of Mimi Peri's identity. Mimi Peri is an Instagram cyber identity innovation that appears to bring a novelty to the identity of the Instagram cyber Indonesia community. Through Mimi Peri's identity, Ahmad Jaelani shifted or disrupted the identity of the Instagram cyber community that had taken place.

\subsection{Disruption of the communication identity of Mimi Peri}

The disruption of identity communication Mimi Peri's on Instagram is an innovation in the form of conveying identity that is different from the existing identity of the Indonesian Instagram's cyber community. There are several views of Mimi Peri's identity which show that she is one of the actors of identity disruption. The appearance of identity includes: gender display, language display, and cultural-behavior display. Where these three views are Ahmad Jaelani's self-presentation and subjective dimensions on his Instagram.

The displays of Ahmad Jaelani's communication identity innovations have disrupted massively the identity of the Indonesian Instagram cyber community. The disruption of identity communication is an innovation, where the innovation is to replace the entire old system with new ways to communicate. Disruption also has the potential to replace the old (incumbent) players with digital technology that produce something truly new with more efficient and more useful [13]. Indonesian cyber communities have guided behaviors according to the life of their reality [22]. Such as behaving politely and politely, carrying out the norms of Indonesian society, and guided according to 'Pancasila'.

\subsubsection{Disruption of Gender Identity}

Gender's appearance represents Ahmad Jaelani, in the identity of Mimi Peri, with professionals playing a role with gender-fluid. Gender-fluid representation of Ahmad Jaelani acts as an 'Angel' with his own costume and clothing. Where this reality is contrary to its original gender identity as masculine gender. Like almost all of the photos and videos uploaded, the innovative subjective dimension is displayed.

Disruption of gender identity is an innovation in representing gender identity. Where this innovation often shifts the norms and rules that have been developed so far. The gender-fluid appearance of Mimi Peri on his Instagram chart is a part of the disruption of communication identity in gender studies. Most Indonesian cyber communities have a paradigm of community 
identity consisting of masculine gender and feminine gender (binary gender). Those who are not included in the binary gender, the group will be isolated and decriminalized. In his attempt to display his gender innovations on Instagram Mimi Peri was faced with rejection and acceptance by the public.

\subsubsection{Disruption of Language Identity}

In addition to innovating with the 'gender fluid' identity display on Instagram, Mimi Peri also has a style of language typical of his own innovative work as a supporter of the identity of 'his angel' on the Instagram. Like Mimi Peri communicates in various languages with followers, where the language is practically incompatible with the standard language structure. In addition, in interacting Mimi Peri also uses his own terms of use which are always used in interactions and represent their identity. These words are like 'keperawananku', 'syantik', 'manjhaa'.

Disruption of language identity is an innovation in displaying new languages, different languages, or updating existing languages. Mimi Peri displays the disruption of the language created by her. In this language it is not in accordance with the rules and language structure used by the Indonesia's Instagram cyber community. Mimi Peri uses her language innovations to communicate with her followers and other cyber society of Instagram.

\subsubsection{Disruption of Cultural-behavior Identity}

Mimi Peri also displays identity innovation related to his behavior. Having an identity as an Indonesian citizen certainly knows his character, norms and culture. The majority of Indonesian people still uphold these cultures and norms, as well as in cyberspace. However, it is different from Ahmad Jaelani. His identity as Mimi Peri shows cultural-behavior innovation by shifting existing ones. Innovative behavior can be said to be 'stupid' or even 'crazy' based on the opinion of the majority of cyber people. The culture-behavior is dancing 'striptease dance', behaving like a 'drag queen', showing it as a 'cheap' person.

The disruption of behavioral and cultural identity is an innovation of delivering new or existing behavior and culture but by adding some things that are creative or unnatural. The disruption made by Mimi Peri in her behavior and cultural identity is Mimi Peri displaying behavior and culture that is not like most of the Indonesia's Instagram cyber society. He made innovations by showing creative and deviant behavior and culture, not in accordance with the behavior and culture held and adopted by Indonesian cyber society.

\subsection{The effect of the Disruption Communication Identity of Mimi Peri}

Mimi Peri in conveying the identity innovation, quickly gets a response behind the Instagram cyber community (follower). Many who respond to many positives also respond negatively. In carrying out relations with other Instagram cyber communities, the delivery of Ahmad Jaelani's cyber identity innovations is much to his liking, as in some photo comments and uploaded videos on his Instagram respond with support and praise, such as the words 'funny', 'beautiful', and others. However, Ahmad Jaelani also received a bad response and swear ridicule, like 'crazy', 'stupid', and others. The response was not only in the form of comments in uploading photos and videos on Mimi Peri's Instagram, but the Instagram cyber community also responded to the innovation of its identity in the form of direct message (DM) and when Mimi Peri broadcasted 'live Instagram'.

From the identity of innovation, Instagram self-presentation, pros and cons of cyber society, Mimi Peri becomes a celebrity and influential person. The disruption of his identity made him known, had many fans, and motivated the emergence of new Instagram actors to disrupt identity within the scope of the Indonesian Instagram cyber community. With the disruption of his 
identity, Mimi Peri won the trust as an endorser at a rate of Rp. 1,000,000.00 to upload one video, while Rp. $500,000.00$ for wages to upload photos. Seeing this phenomenon makes the disruption of the identity of the Indonesian cyber community spread and become a very big phenomenon today.

\section{CONCLUSION}

In conclusion, Ahmad Jaelani disrupted the communications identity of cyber Instagram as Mimi Peri. The disruption of communication identity he did was the disruption of gender identity, disruption of language identity, and disruption of cultural-behavior identity. Starting from innovation, creativity, and the attitude of Ahmad Jaelani in the real life, then applied in cyberspace Instagram in the form of Mimi Peri, Ahmad Jaelani managed to create and spread the phenomenon of communication identity disruption to the Instagram cyber community in Indonesia. This step is a form of CMC dynamism. Where Ahmad Jaelani managed to spread the phenomenon of communication identity disruption through Instagram. This phenomenon of disruption of identity communication raises a new perspective that someone can change fate if he wants to innovate and strive hard. The disruption of communication identity also has good effects and adverse effects. Like, it can create economic equality and create a variety of bars. On the other hand it also causes loss and fading of existing norms. As in this article which presents received the disruption of communication identity on the Indonesian Instagram's cyber community.

\section{REFERENCES}

[1] J. G. Shalom, H. Israeli, O. Markovitzky, and J. D. Lipsitz, "Social Anxiety and Physiological Arousal During Computer Mediated vs. Face to Face Communication," Computers in Human Behavior, vol. 44, pp. 202-208, 2015.

[2] A. Ghezzi, L. Gastaldi, E. Lettieri, A. Martini, and M. Corso, "A Role Stratups in Unleashing the Disruptive Power of Social Media," International Journal of Information Management, vol. 36, pp. 1152-1159, 2016.

[3] C. A. Jackson and A. F. Luchner, "Self-Presentation Mediates The Relationship between Self-Criticism and Emotional Response to Instagram Feedback," Personality and Individual Differences, vol. 133, pp. 1-6, 2018.

[4] Jelajah Digital, "Data dan Fakta Instagram dalam Statistik," JelajahDigital.com, https://jelajahdigital.com/data-dan-fakta-instagram-dalam-statistik/. Accessed on March $19,2019$.

[5] S. V. Jin, "Celebrity 2.0 and Beyond! Effects of Facebook Profile Sources on Social Networking Advertising," Computer in Human Behavior, vol. 79, pp. 154-168, 2018.

[6] R. Cohen, L. Irwin, T. N.-John, and A. Salter, "\#bodypositivity: A Content Analysis of Body Positive Accounts on Instagram," Body Image, vol. 29, pp. 47-57, 2019.

[7] L. R. Ramsey and A. L. Horan, "Picture This: Women's Self-Sexualization in Photos on Social Media," Personality and Individual Differences, vol. 133, pp. 85-90, 2018.

[8] T. M. Dumas, M. M.-Smith, J. P. Davis and P. A. Giulietti, "Lying or Longing for Likes? Narcissism, Peer Belonging, Loneliness and Normative Versus Deceptive Like-Seeking on Instagram in Emerging Adulthood," Computer in Human Behavior, vol. 71, pp. 1-10, 2017.

[9] C. Lee and D. Chau, "Launguage as Pride, Love, and Hate: Archiving Emotions Through Multilingual Instagram Hashtags,” Discourse, Context \& Media, vol. 22, pp. 21-29, 2018. 
[10] C. Feder, "The Effects of Disruptive Innovations on Productivity," Technological Forecasting \& Social Change, vol. 26, pp. 186-193, 2018.

[11] M. J. Sousa and A. Rocha, "Skill for Disruptive Digital Business," Journal of Business Research, vol. 94, pp. 257-263, 2019.

[12] D. Nagy, J. Schuessler, and A. Dubinsky, "Defining and Identifying Disruptive Innovations," Industrial Marketing Management, vol. 57, pp. 1192-126, 2016

[13] R. Kasali, "Disruption: Tak Ada yang Tak Bisa Diubah Sebelum Dihadapi Motivasi Saja Tidak Cukup (Cetakan ketujuh),” Jakarta: PT Gramedia Pustaka Utama, 2018.

[14] E. Gemici and L. Alpkan, "An Application of Disruptive Innovation Theory to Create a Competitive Strategy in Turkish Air Transportation Industry," Procedia - Social and Behavioral Sciences, vol. 207, pp. 806, 2015.

[15] M. Li, A. I. Porter, and A. Suomunen, "Insights into Relationhips between Disruptive Technology/ Innovation and Emerging Technology: A Bibliometric Perspective," Tecnological Forecasting \& Social, vol. 129, pp. 285-296, 2018.

[16] J. Guo, J. Pan, J. Guo, F. Gu, and J. Kuusisto, "Measurement Framework for Assessing Disruptive Innovations," Technological Forecasting \& Social Change, vol. 139, pp. 2590265, 2019.

[17] K. Kilkki, M. Mantyla, K. Karhu, H. Hammainen, and H. Ailisto, "A Disruption Framework," Technological Forecasting \& Social Change, vol. 129, pp. 275-284, 2018.

[18] O. Dedehayir, T. Nokelainen, and S. J. Makinen, "Disruptive Innovations in Complex Product Systems Industries: A Case Study," Journal of Engineering and Technology Management, vol. 33, pp. 174-192, 2014.

[19] S. W. Littlejohn dan K. A. Foss, "Theories of Human Communication (Tenth Edition)," United States of America: Waveland Press, Inc, 2011.

[20] I. Gomaa, A. M. Said, E. A. Elrahman, A. Hamdy, and E. M. Saad, "Performance Evaluation of Virtual Identity Approaches for Anonymous Communication in Distributed Environments," Procedia Computer Science, vol. 109C, pp. 710-717, 2017.

[21] M. Allen, "The Sage Encyclopedia of Communication Research Methods," Sage Publications, 2017.

[22] B. Bungin, "Sosiologi Komunikasi (Cetakan ke-sembilan)," Jakarta: Kencana, 2017. 